\title{
LEAN MEAT CONTENT OF PIG CARCASSES IN THE EIGHT SLAUGHTERHOUSES IN THE REGION OF VOJVODINA, SERBIA
}

Ivan V. Radović, Miroslava S. Polovinski-Horvatović*, Mile J. Mirkov, Savo Z. Malešević

University of Novi Sad, Faculty of Agriculture, 21000 Novi Sad, Trg Dositeja Obradovića 8, Serbia

\begin{abstract}
The end product of the pig production is carcass. Lean meat content is a measure of the quality of the carcass. Serbia is one of only a few countries in Europe which has not yet adopted the practice of pig's carcasses classification and failed to regulate this issue through legislation. The purpose of this work was to measure lean meat content in carcasses probed in several slaughterhouses in the Province of Vojvodina (northern Serbia) and to classify them according to the SEUROP classification. In total it was classified 65764 pig carcasses in eight different slaughterhouses. The lean mean content was measured on the slaughter line 45 minutes post mortem with the one-point puncture model. The measurement was carried out with the optoelectronic probe for the classification of pig carcasses CLASSPRO GmbH (Germany). The percentage of meat in the carcass was calculated using the mathematical model. In all eight slaughterhouses in which the measurements were done there was no poor quality ( $\mathrm{P}$ class) pig carcass. The majority of carcasses were in the class E-excellent (35545 carcasses or $54.05 \%$ in total) and U-very good (25864 carcasses or $39.33 \%$ in total). However, a very small number of the carcasses were in the superior class with more than $60 \%$ of lean meat content, only 2072 carcases or $3.15 \%$ in total. Any future effort which the government would put in the implementation of the system of pricing of pigs based on the carcass characteristics would have enormous effect on the pig production in general. The pig producers would have the reason to invest in better farm management, selection in effort to improve the quality of the end products-pigs. In addition, the meat industry would certainly have benefits by having a higher quality raw material for further processing.
\end{abstract}

Key words: pig production, lean meat, classification

\section{INTRODUCTION}

The pig production is important part of animal production in Serbia. By the official statistic data the production of pigs and pig meat in Serbia is about 300 thousands of tons of meat per year (Statistical Yearbook, 2018). Accor- ding to this data the biggest production of meat in Serbia is the production of pork. In comparison to the rest of the animal production in Serbia the pig production is the most developed. Serbia is a part of the Central 
European Free Trade Agreement (CEFTA). Among all countries which are members of CEFTA Serbia has the best possibilities for the production of pigs and it is the main producer (van Bussel - van Lierop, van Wagenberg \& Somers, 2015). Also, there is a huge possibility for export to the Russian Federation which resulted in increased export from USD 20.8 thousand to USD 58 million from 2004 to 2014 (Jeremić, Koviljko \& Matkovski, 2018).

However, all animal productions have been in crisis for a few years in a row including the pig production in Serbia. One of the problems is the existence of a large number of small farms.

There are about 400 commercial farms with very different agricultural practice and the usage of up-to-date technologies (van Bussel van Lierop et al., 2015). The outbreak of African swine fever (ASF) in some of the neighbouring countries and its appearance in the central part of Serbia significantly rocked the primary producers and made them more wary for some future developments and investments in swine production. In a past few years, in several occasions, the export of pork to the Russian Federation has been stopped which affected the pig production, too.

The pigs are usually produced from the F1 sows mated with the terminal boars to obtain the best possible characteristics of the lean meat content, feed intake and feed conversion.

Some estimations indicated that heritability for the lean meat content is approximately from 0.42 to 0.57 , so this characteristic can be relatively quickly improved by good selection practice (Knapp, Willam \& Sölkner, 1997). Also, well balanced nutrition has the same importance for the quality of carcass.

The usual practice in the EU is the classifycation of carcasses on the slaughter line and grading (SEUROP) according the estimated lean meat content (Jansons et al., 2016). By this method farmers are stimulated to produce pigs with higher average lean meat content and gain higher price of their pigs.
Classification of pig carcasses is not the usual practice in slaughter houses in Serbia, and it is not clearly regulated trough the legislation. Moreover, Serbia is one of only a few countries in the Europe which still does not practice this kind of classification. The pricing of pigs in the majority of slaughterhouses is done by the live weight of pigs. By this principle the good producers are not rewarded for their extra effort.

This work aimed at preliminary classification of pig carcasses based on lean meat content in 8 slaughterhouses of different capacities in Serbia.

\section{MATERIALS AND METHODS}

In the period from January to December 2018 the classification of the pig carcasses in eight slaughterhouses on the territory of the Province of Vojvodina (northern Serbia) was done. The slaughter houses were very different in their capacities; from the very small ones with only a few dozens of pigs per day (slaughterhouse 1) to the huge industrial slaughterhouses with about one thousand slaughter pigs per day (slaughterhouse 6).

Three qualified operators performed the classification of pig carcasses. The operators had finished the training courses in Norway, in the agency for classification 'Nortura', and in Italy, in the organization of the Italian Ministry "Ministero delle Politic he Agricola Alimentary e Forestali" for which they received certificates.

In total, 65764 pig carcasses were classified in eight different slaughterhouses. The lean meat content was measured on the slaughter line 45 minutes post mortem with the one-point puncture model. The measurement was carried out with an optoelectronic probe for the classification of pig carcasses CLASSPRO GmbH (Germany).

The puncture was $7 \mathrm{~cm}$ from medial carcass line, between $3^{\text {rd }}$ and $4^{\text {th }}$ rib, from cardocranial point of view, perpendicularly to the carcass. Percentage of meat in the carcass was calculated using the mathematical model developed by Petrović (2009): 
where:

LF is fat tissue thickness (with skin) in millimeters, measured $7 \mathrm{~cm}$ away from medial carcass line, between $3^{\text {rd }}$ and $4^{\text {th }}$ lumbal vertebrae, from caudo-cranial point of view;

$\mathrm{RM}$ is diameter of $M$. longissimus dorsi (MLD) in millimeters, measured at the same time and in the same position as LF.

Based on the carcass conformation and lean meat content, carcasses were classified according to the SEUROP classification (European Commission, 2008) in the following six categories:

- $\mathbf{S}$ - superior, $60 \%$ lean meat or more;

- $\mathbf{E}$ - excellent, from $55 \%$ lean meat to less than $60 \%$;

- $\mathbf{U}$ - very good, from $50 \%$ lean meat to less than $55 \%$;

- $\quad \mathbf{R}$ - good, from $45 \%$ lean meat to less than $50 \%$;

- $\mathbf{O}$ - fair, from $40 \%$ lean meat to less than $45 \%$;

- $\quad \mathbf{P}$ - poor, less than $40 \%$ lean meat.

The basic descriptive statistical data analysis was done by using the software package TIBCO ${ }^{\circledR}$ Data Science Statistica ${ }^{\text {TM }} 14$ released in 2020 (TIBCO Software Inc., Palo Alto, California).

\section{RESULTS AND DISCUSSION}

The results of the carcass classification are presented in the Table 1. In all eight slaughterhouses in which the measurements were done there were no pig carcasses in the $\mathrm{P}$ class. The majority of carcasses were in the class E (35545 carcasses or $54.05 \%$ in total) and $U$ (25864 carcasses or $39.33 \%$ in total). However, a very small number of the carcasses were in the superior class with more than $60 \%$ of lean meat content, only 2072 carcasses or $3.15 \%$ in the total.

The biggest number of classified carcasses was from the slaughterhouse under the number 6 , in total 33720 pigs carcasses, or $51.27 \%$ in total. The number of the carcasses per slaughterhouses was very different, from 274 carcasses (in slaughterhouse No. 1) to 33720 (in slaughterhouse No. 6) due to their different capacities.

The average lean meat content in all eight slaughterhouses was $55.31 \%$, while the lowest mean level was in the slaughterhouse No. 8, and the highest in slaughterhouse No. 6 (Table 2). Maximum registered value was $68.56 \%$ while minimum was $40.48 \%$ (Table 2).

Table 1.

Number (N) and percent of pig carcasses classified by the SEUROP standard in eight slaughterhouses in the region of Vojvodina, Serbia

\begin{tabular}{|c|c|c|c|c|c|c|c|c|c|c|c|c|c|c|}
\hline \multirow{4}{*}{ 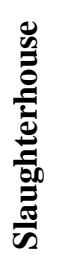 } & \multicolumn{12}{|c|}{ Carcass classes based on the mean lean meat content $(\%)$} & \multirow{2}{*}{\multicolumn{2}{|c|}{ Total }} \\
\hline & \multicolumn{2}{|c|}{$<40 \%$} & \multicolumn{2}{|c|}{$40-45 \%$} & \multicolumn{2}{|c|}{$45-50 \%$} & \multicolumn{2}{|c|}{$50-55 \%$} & \multicolumn{2}{|c|}{$55-60 \%$} & \multicolumn{2}{|c|}{$>60 \%$} & & \\
\hline & \multicolumn{2}{|c|}{$\mathbf{P}$} & \multicolumn{2}{|c|}{$\mathbf{O}$} & \multicolumn{2}{|c|}{$\mathbf{R}$} & \multicolumn{2}{|c|}{$\mathbf{U}$} & \multicolumn{2}{|c|}{$\mathbf{E}$} & \multicolumn{2}{|c|}{$\mathbf{S}$} & & \\
\hline & $\mathbf{N}$ & $\%$ & $\mathbf{N}$ & $\%$ & $\mathbf{N}$ & $\%$ & $\mathbf{N}$ & $\%$ & $\mathbf{N}$ & $\%$ & $\mathbf{N}$ & $\%$ & $\mathbf{N}$ & $\%$ \\
\hline 1 & & & 2 & 0.00 & 42 & 0.06 & 183 & 0.28 & 45 & 0.07 & 2 & 0.00 & 274 & 0.42 \\
\hline 2 & & & 23 & 0.03 & 388 & 0.59 & 3499 & 5.32 & 4372 & 6.65 & 228 & 0.35 & 8510 & 12.94 \\
\hline 3 & & & 6 & 0.01 & 306 & 0.47 & 6444 & 9.80 & 8327 & 12.66 & 233 & 0.35 & 15316 & 23.29 \\
\hline 4 & & & & 0.00 & 104 & 0.16 & 2819 & 4.29 & 3219 & 4.89 & 103 & 0.16 & 6245 & 9.50 \\
\hline 5 & & & & 0.00 & 8 & 0.01 & 185 & 0.28 & 160 & 0.24 & 5 & 0.01 & 358 & 0.54 \\
\hline 6 & & & 60 & 0.09 & 1097 & 1.67 & 12129 & 18.44 & 18928 & 28.78 & 1506 & 2.27 & 33720 & 51.25 \\
\hline 7 & & & 21 & 0.03 & 135 & 0.21 & 449 & 0.68 & 426 & 0.65 & 5 & 0.01 & 1036 & 1.58 \\
\hline 8 & & & 4 & 0.01 & 73 & 0.11 & 156 & 0.24 & 68 & 0.10 & 4 & 0.01 & 305 & 0.46 \\
\hline Sum & - & - & 116 & 0.18 & 2153 & 3.27 & 25864 & 39.33 & 35545 & 54.04 & 2086 & 3.15 & 65764 & 100.00 \\
\hline
\end{tabular}


Table 2.

The basic statistical data regarding lean meat content from the eight slaughterhouses

\begin{tabular}{cccccc}
\hline Slaughterhouse & $\mathbf{N}$ & $\begin{array}{c}\text { Average } \\
(\boldsymbol{\%})\end{array}$ & Min (\%) & $\begin{array}{c}\text { Range } \\
\text { Max (\%) }\end{array}$ & $\begin{array}{c}\text { Standard } \\
\text { deviation }\end{array}$ \\
\hline 1 & 274 & 52.67 & 43.59 & 61.29 & 2.76 \\
2 & 8510 & 55.04 & 40.72 & 64.60 & 2.81 \\
3 & 15316 & 55.22 & 42.89 & 63.34 & 2.35 \\
4 & 6245 & 55.16 & 45.16 & 63.55 & 2.34 \\
5 & 358 & 54.90 & 47.83 & 62.11 & 2.38 \\
6 & 33720 & 55.55 & 40.81 & 68.55 & 2.82 \\
7 & 1036 & 53.68 & 40.48 & 60.27 & 3.50 \\
\hline & 305 & 52.38 & 42.72 & 61.32 & 3.51 \\
\hline Sum & $\mathbf{6 5 7 6 4}$ & $\mathbf{5 5 . 3 1}$ & $\mathbf{4 0 . 4 8}$ & $\mathbf{6 8 . 5 6}$ & $\mathbf{2 . 7 1}$ \\
\hline
\end{tabular}

$N$-number of sampled pig carcasses

Data from the neighbouring former Yugoslavian countries indicate that implementation of the SEUROP classification standard gave good feedback results. Slovenia had the obligatory standard from 1985, the time of former Yugoslavia (partially this standard is still in use in Serbia). From the time of becoming independent country, the old system was abandoned and the payment according to the live weight prevailed in practice. In 1996, a new standard based on the EU regulation was introduced. During the eight years of practicing the pig carcass classification based on the SEUROP system, an important increase in average lean meat content from 51.9 to $55.9 \%$ was noted. At the same time, the number of pig carcasses classified in the classes $\mathrm{S}$ and $\mathrm{E}$ were almost tripled (Čandek-Potokar, Kovač \& Malovrh, 2005). Croatia has also implemented the system based on the EU regulation for the carcass classification in 1999 (Kušec et al., 2007).

Romania started to implement the EU system for the grading pig carcass from the $1^{\text {st }}$ March 2006. The results from 2009 indicated the improvement in pig carcass quality as the result of the implementation of carcass classification (Balan et al., 2010). From 2009 to 2015 the average lean meat content in carcasses measured in Romania increased from the 59.1 to 59.9\% (Cărătuş Stanciu \& Găureanu, 2019). Similarly, in Bulgaria, an increase in the lean meat content was observed as a result of the implementation of SEUROP standard for pig classification (Nakev \& Popova, 2019).
In Serbia several investigations were done regarding the quality of pig carcasses, however, none to such extent as in this study. The focus of these studies was the use of a different system of classification, formula, effect of genotype of pigs on the percentage of lean meat (Kosovac, Stanišić, Živković, Radović \& Pejčić, 2008) and, to a lower degree, the distribution of classes classified by SEUROP and a number of samples of pig carcasses. In the study done by Kosovac (2009), 135 carcasses were classified in the medium quality range $(\mathrm{E}$, U and R).

The data from our study indicate that there was a difference in the percentage of certain groups of classified carcasses among the monitored slaughterhouses.

Thus, the highest percent of carcasses in the $S$ superior class was registered in the slaughterhouse No. 6, while the highest percent of the carcasses in the group $\mathrm{O}$ was obtained in the slaughterhouse No. 7. It should be kept in mind that there is a huge difference in the capacity among the eight slaughterhouses. In smaller slaughterhouse, fattening pigs and pigs from smaller producers mostly end up, while large industrial slaughterhouses are mainly associated with large farms and intensive rearing.

However, all observed data indicate that in any case, both for smaller and larger producers, the introduction of the classification of carcasses on the slaughter line would have a good feedback effect on the basic production of pigs. 


\section{CONCLUSIONS}

Serbia is one of the rare if not the only country in the region which does not apply the practice or legislation for the pig carcasses classifycation. Also, at the same time, Serbia has excellent conditions for further development of pig production and de facto the pig production is more vital branch than any other type of animal production. Legislation regarding the market of pig carcasses and pig classification is long time overdue for changes. If it is updated, it should push the pig production in a good direction. Pricing of pigs based on the live weight at the slaughterhouses does not stimulate the farmers to produce pigs with the desirable carcass characteristics. Carcass is the end product of the pig production and the start product of the meat industry. Any future effort of the government put in the implementation of the system of pricing pigs based on the carcass characteristics would have an enormous effect on the pig production in general. The pig producers would have motivation to invest in better farm management and selection as well as to put extra effort to improve the quality of the end products-pigs. This would have positive impact on meat processors by providing better quality raw material.

\section{ACKNOWLEDGEMENTS}

The study is the result of the project entitled 'The carcass classification of pigs on the slaughter line', number 104/401-7097/2017-03 financed by the Provincial Secretariat for Agriculture, Forestry and Water Management.

\section{REFERENCES}

Balan, I. M., Petroman, C., Petroman, I., Marin, D., Ciolac, R., Heber, L., \& Orboi D.M. (2010). Romanian quality pork carcasses in 2009. Animal Science and Biotechnologies, 43(2), 389-390. https://www.spasb.ro/index.php/spasb/article/view 1916

Cărătuș Stanciu, M., \& Găureanu, M.E. (2019). Technical aspects regarding the pig classification carcasses in Romania between 2009-2015, by semiautomated method OptiGrade Pro. Annals "Valahia" University of Targoviste - Agriculture, 13(1), 44-49. https://doi.org/10.2478/agr-2019-0010.

Čandek-Potokar, M., Kovač, M., \& Malovrh, Š. (2005).
Slovenian experience in pig carcass classification according to SEUROP during the years 1996 to 2004. Journal of Central European Agriculture, 5(4), 323-330.

https://doi.org/10.5513/jcea.v5i4.233.

European Commission. (2008). Commission Regulation (EC) No. 1249/2008. Official Journal of the EU, L337/3, 3-30.

Jansons, I., Strazdina, V., Anenkova, R., Pule, D., Skadule, I., \& Melece, L. (2016). Development of new pig carcasses classification formulas and changes in the lean meat content in Latvian pig population. Agronomy Research, 14(S2), 13061314.

https://bior.lv/sites/default/files/publikacijas/L_a_2 30_Development\%20of\%20new\%20pig\%20carcas ses\%20classification.pdf

Jeremić, M., Koviljko, L., \& Matkovski, B. (2018). Serbian pork market analysis. Ekonomika poljoprivrede, 65(4), 1449-1460. https://doi.org/10.5937/ekopolj1804449j.

Knapp, P., Willam, A., \& Sölkner J. (1997). Genetic parameters for lean meat content and meat quality traits in different pig breeds. Livestock Production Science, 52(1), 69-73. https://doi.org/10.1016/S0301-6226(97)00120-6.

Kosovac, O. (2009). Quality of pig carcasses on slaughter line according to previous and current EU regulation. Biotechnology in Animal Husbandry, 25(5-6), 791-801.

Kosovac, O., Stanišić, N, Živković, B., Radović, Č., \& Pejčić, S. (2008). Quality of pig carcass and meat of different genotypes. Biotechnology in Animal Husbandry, 24(1-2), 77-86. https://scindeks-clanci.ceon.rs/data/pdf/14509156/2008/1450-91560802077K.pdf

Kušec, G., Durkin, I., Petričević, A., Kralik, G., Maltar, Z., Margeta, V., \& Hanžek D. (2007). Equations for lean share estimation in swine carcasses in Croatia. Poljoprivreda, 13(1), 70-73.

Nakev, J., \& Popova T. (2019). Results of the application of SEUROP for pig carcass classification in Bulgaria. Bulgarian Journal of Agricultural Science, 25, 17-22.

http://www.agrojournal.org/25/01s-04.pdf

Petrović, LJ. (2009). Definisanje parametara i kriterijuma za ocenu kvaliteta polutki svinja u cilju izrade predloga pravilnika o kvalitetu zaklanih svinja i kategorizaciji svinjskog mesa.

http://www.minpolj.gov.rs/download/izvestaj.pdf

Statistical Yearbook. (2018). Statistical Yearbook of the Republic of Serbia, year 2018, (D. Gavrilović Ed.). Belgrade: Statistical Office of the Republic of Serbia. https://www.stat.gov.rs/enus/publikacije/publication/?p=11525

van Bussel - van Lierop, A., van Wagenberg, C., \& Somers, D. (2015). Serbian pig sector: an overview. Livestock Research Report 843. Wageningen UR Livestock Research. https://edepot.wur.nl/346887 


\section{ODREĐIVANJE MESNATOSTI POLUTKI TOVLJENIKA U OSAM KLANICA U REGIONU VOJVODINE, SRBIJA}

Ivan V. Radović, Miroslava S. Polovinski-Horvatović, Mile J. Mirkov, Savo Z. Malešević

Univerzitet u Novom Sadu, Poljoprivredni fakultet u Novom Sadu, Departman za stočarstvo, 21000 Novi Sad,

Trg Dositeja Obradovića 8, Srbija

Sažetak: Krajnji proizvod proizvodnje svinja je trup zaklane životinje. Procenat mesa je mera kvaliteta trupa. Srbija je jedna od nekolicine zemalja u Evropi koja još uvek ne vrši klasifikaciju svinjskih trupova i koja nije zakonski regulisala klasifikaciju trupova. Cilj ovog rada je bio da se izvrši klasifikacija svinjskih trupova u nekoliko klanica u Vojvodini prema SEUROP sistemu klasifikacije trupova. Ukupno je određena mesnatost kod 65764 trupova svinja u osam različitih klanica. Mesnatost se određivala 45 minuta post mortem metodom jedne tačke. Merenje je izvršeno optoelektronskom sondom za klasifikaciju svinjskih trupova CLASSPRO Gmbh (Germany). Ubodno mesto je $7 \mathrm{~cm}$ od medijalne linije trupa, između 3 i 4 rebra. Procenat mesnatosti u trupu se izračunavao na osnovu matematičkog modela. U svih osam klanica nijedan trup nije bio u klasi P. Većina polutki je bila u klasi E (35545 trupova ili 55,62\% ukupno) i u klasi U (25864 trupova ili 37,87\% ukupno). Međutim, veoma mali broj trupova je bio u klasi S sa više od $60 \%$ mesnatosti, samo 2086 trupova ili 3,5\% ukupno. Svaki budući napor države usmeren ka primeni sistema otkupa tovljenika na osnovu kvaliteta trupa imaće ogroman efekat na proizvodnju svinja. Uzgajivači bi bili motivisani da investiraju u farmski menadžment i selekciju da bi poboljšali kvalitet proizvoda-svinja. S druge strane, ovo bi se povoljno odrazilo na mesnu industriju jer bi na raspolaganju imala kvalitetniju polaznu sirovinu.

Ključne reči: proizvodnja tovljenika, mesnatost, klasifikacija

Received: 28 January 2021/Received in revised form: 04 March 2021/ Accepted: 11 March 2021

Available online: March 2021

This is an open-access article under the CC BY license (http://creativecommons.org/licenses/by/3.0). 